\title{
Young people as a subject of human resources management in the third sector organizations
}

Prof. Janina Stankiewicz University of Zielona Góra

Faculty of Economics and Management

Bartosz Seiler, Ph.D. University of Zielona Góra

Faculty of Economics and Management

Hanna Bortnowska, Ph.D. Eng.

University of Zielona Góra

Faculty of Economics and Management

\section{Introduction}

In today's world, the sphere of social life is increasingly subject to rationalization processes and, citing M. Weber (2011), to "disenchantment". A testament to this is, among other things, management expansion, which allows for improved efficiency of the functioning of various entities: individuals, organizations, territorial communities. They plan their activities, organize, motivate, and then control the results.

One manifestation of this expansion is the dissemination of managementmethods notonly in companies, but also in social organizations (third-sector, non-profit, non-governmental, civic, voluntary) which have been gaining significance since the 1970s, becoming part of the so-called civic administration and participating in the process of delivering public goods. This phenomenon aroused the interest of theoreticians and management practitioners (Anheier 2005), who took up the consideration of administering this sphere of social life.

According to J. Fudaliński (2013, p. 102), management in non-profit organizations 
can be considered from two perspectives. In the macro-dimension, it refers to the concept of civil society and perceives the individual as part of a broader community. In the micro-dimension, meanwhile, it refers to specific activities related to the functioning of a third-sector organization. By interpreting the thought of the author cited above, it can be said that every citizen who sets up or joins a non-profit organization engages in the management of their chosen area of social life. Then, social entrepreneurs and voluntary workers become active, structuring and managing the organization they made up.

When looking at civic organizations from a micro-perspective, one can see that their primary resource is social workers (cf. Bussell, Forbes 2002; Rodwell, Teo 2008). These organizations are "labor-intensive", employing unpaid work of members and volunteers. They can continue their activities under unfavorable conditions, relying on the enthusiasm and commitment of the volunteers. It should be added that the characteristic feature of the discussed entities is the varied structure of the staff. They operate not only through the social involvement of members, program board members, external volunteers (both formal and informal), but also paid workers.

Managing a structurally diverse staff is a challenge and requires appropriate skills from the leaders of the civic organizations. Some authors exploring the non-profit sphere find it useful to introduce methods and techniques for managing human resources in the third sector (Baluch McCandless 2012; Bogacz 2009; Burke, Cooper 2012; Day 2013; Drucker 1995; Hudson 1997; Kafel 2014; Pynes 2013; Rustecki 2011; von Eckardstein, Brandl 2004). They propose the following solutions: professional recruitment, selection and adaptation, motivating staff members, developing their competence, and evaluating their performance. However, the implementation of these measures may encounter some cultural or mental barriers, which are related to insufficient knowledge in this respect. The introduction of business management methods may, as shown in the analysis of the literature (see Bartoszek, Dabrowska-Pięda 2009; Mulhare 1999), demonstrate resistance to the ethos of the third sector, thereby leading to cultural conflict within the organization. And last but not least, to being seen as counter-effective - responsible for bureaucratization and formalization of activities that are inherently amateurish and spontaneous.

The results of the third-sector research show that the community in these organizations is built under conditions of democratic governance, within a specific organizational culture that characterizes the organizations. This requires that their managers take into account that organizations they manage 
gather together employees representing different social categories, made of agediverse people such as: students, people in working age and retirees. The largest group of volunteers are young activists aged 15-24 (GUS, 2016). Volunteering is an opportunity for them to have a wide range of their needs met, including those related to self-improvement, skill acquisition, both civic and those required by the labor market (cf. Baranyi 2011; McGinnis 2011). At the same time, some of them later transfer onto paid work in organizations of the third sector. The results of available research studies show that people below 30 are the fifth part of all employees in the civic organizations (Adamiak et al., 2016). It is interesting to know how young people interact with non-profit organizations and how they evaluate them.

The purpose of the article is to identify the number and types of thirdsector organizations, which young people have been involved in, as well as the characteristics of work performed by them in those subjects. Moreover, the article's aim is to diagnose of personal processes that these persons have been engaged in and to ascertain how do they evaluate their work experience in the organizations, which were analyzed. In order to achieve these goals, an empirical study was conducted.

\section{Research methodology and research sample characteristics}

The study covered the years 2011-2015 and focused on the activities of Lubuskie Province non-governmental organizations, addressing the issue of the management in the third sector at the macro-level (expressed, among other things, in the manner and area of involvement of respondents) and microlevel (in the field of human resources management methods used in non-profit organizations, such as the selection of employees, their development, motivation or evaluation).

The direct survey technique was used, using a categorized and standardized questionnaire. Nine questions were asked - some closed and others half open. The ordinal and Likert-type scales were used. Socio-demographic variables of study participants were taken into account as well.

During the research, the opinions of 108 specifically selected respondents ${ }^{1}$ young residents of Lubuskie Province - were analyzed. Every tenth (11.1\%) was

1 Given the inability to determine the size of the general population, a decision was made to perform a deliberate rather than random sample selection. The research is, in principle, a pilot study and provides an introduction to the broader explorations of young people's (up to 26 years old) participation in the non-profit sphere.

Young people as a subject of human resources management in the third sector 
below 18 years of age, and one is six (15.7\%) were in the 18-19 age range. The majority of the respondents $(42.6 \%)$ were 20 or 21 , while almost one-third $(30.6 \%)$ were over 22 years old. There were more women (63.9\%) than men among the respondents.

\section{Young people's involvement in the activities of third-sector organizations}

The third sector is the sphere of civic engagement, cooperation of free individuals, acting in the public interest (Glinski 2006). Young people can influence social management by engaging in various types of non-profit organizations.

The research shows the involvement of young people in the social sphere is seldom persistent and formal. Almost half of the respondents (46.3\%) participated in the activities of one non-profit organization, with onethird $(33.3 \%)$ - in two, and one-seventh $(14.8 \%)$ - in three. Few engaged in the functioning of four $(3.7 \%)$ or five $(1.9 \%)$. Involvement in the form of volunteering, including mainly informal one, without a voluntary employment contract, was predominant [78.7\%; only one out of every five respondents $(22.2 \%)$ signed such an agreement]. Fewer than one in five respondents (18.5\%) served as members of a particular non-profit organization, which required payment of contributions, participation in general meetings, etc. The respondents were significantly less likely to hold managerial positions (fewer than $8 \%$ in the governing bodies of the organizations in question as representatives of the management board, audit committee, etc.), which could be due to the young age of the respondents and their inadequate skills and professional experience. Even fewer surveyed $(4,6 \%)$ paid for nongovernmental organizations, but this can be explained by the difficulties faced by employers in financing jobs (donators are reluctant to send cash for staffing, while organizations have low capability to self-generate resources for this purpose).

Ephemeral involvement of the respondents could also stem from the fact their job was usually reduce to one-off activities $(70.4 \%)$, although among them there were also those who declared permanent $(25.9 \%)$ or periodic $(21.3 \%)$ commitment.

Participants in the research decided to engage in social areas such as social and humanitarian aid, rescue $(70.4 \%)$, health care $(22.2 \%)$, sport, tourism, recreation (22.2\%), civic initiatives (21.3\%), local development (18.5\%), home education, school education and research (17.6\%). Every second respondent (50.9\%) directly 
provided assistance to those in need by doing homework, providing psychological support, taught. Few $(43.5 \%)$ prepared and hosted events, festivals, conferences. One in four $(25 \%)$ were involved in raising funds for the organization where they were active. A fifth part of the respondents $(20.4 \%)$ was disseminating information important for attaining the statutory goals of third-sector entities selling leaflets, magazines, posters, etc. Among the respondents, there were also office workers $(7.4 \%)$.

The research demonstrates that over a third of the respondents $(80.6 \%)$ evaluated their work experience in the third sector as at least good. Almost all $(99 \%)$ would recommend others to engage in non-profit activities.

To sum up, the involvement of the surveyed young labor market participants in the activity of the third sector is ephemeral, i.e. rarely long-term or formalized. They usually perform executive functions, and only occasionally handle management-related matters. Their cooperation with non-profit entities most often takes the form of one-off voluntary activity, where they engage in social and humanitarian aid, directly providing services to those in need.

\section{Managing young employees of third-sector organizations - selected aspects of HRM}

Young people engage in social activities by working with specific non-profit organizations. It is important for the functioning of the third sector to ensure the quality of the management processes in these entities. This is particularly true of human resource management (HRM) activities, ranging from planning and broadly understood human resource recruitment, motivation, development and evaluation, to the completion of collaboration. In the case of non-governmental organizations, these activities are of particular significance due to limited access to other resources (financial, tangible, etc.).

From the perspective of the effective functioning of an organization of the third sector, it is important to recruit employees (cf. Ahmed 2013; Vijaya, Karibasaveshwara 2014). One of the obstacles in this regard is limited financial resources, as well as the unwillingness of managers to overreach administrative costs resulting from their fear of unfavorable social reaction. As a result, thirdsector organizations may more often than not prefer passive recruitment methods, while active ones use those that do not involve high costs, such as payfree involvement of third parties (contacting potential volunteers, etc.). This is confirmed by the results of the study, which shows that the respondents reported

Young people as a subject of human resources management in the third sector 
accession to the subjects in question primarily as a result of informal influences from educators and teachers $(45.4 \%)$ or family members, friends (39.8\%). Nearly every second $(44.4 \%)$ respondent showed initiative by searching for a foundation or an association on their own. Among them, almost half (45.9\%) had a definite vision of their commitment. Much less effective in the recruitment process was the announcement in the media, printed materials ${ }^{2}$. Only $10 \%$ of the respondents $(10.2 \%)$ were encouraged by such means to undertaking the activity in the third sector.

The last step in the positive process of selecting employees is the sociooccupational adaptation. Its purpose is primarily to: make it easier for new people to learn their roles in the organization, to shape a positive attitude towards the non-profit entity. As a result, they increase their productivity and thus achieve satisfactory results, which can lead to a longer and more favorable relationship (see: Ciekanowski 2010; Penc 2007; Żarczyńska-Dobiesz 2008).The research also indicates that non-profit organizations have taken measures to better understand the specifics of their habits, culture, and the extent of their responsibilities, and to integrate them socially into the team. Actually, the adaptation was conducive to the efficient performance of the tasks given by the employees and increased their satisfaction from the work. It was found that for a significant proportion of the respondents $(40.7 \%)$, the function of a mentor - one who would identify desirable behaviors, offer support, point to the right direction of self-actualization - created a favorable working environment. One in three respondents $(32.4 \%)$ participated in training to prepare for the proper fulfillment of their duties. Less commonly were used activities that were "depersonalized" in nature: providing brochures or other information about the scope of the organization's activities $(32.4 \%)$ and/or printed materials explaining the nature of the assigned tasks (24.1\%). It is worth noting that not every research participant has received professional help in adapting to a new workplace. One in four respondents $(26.9 \%)$ received no support because - they thought - there was no need for it. A small percentage $(1.9 \%)$ of the respondents were not assisted in the implementation process, although they thought it necessary (Stankiewicz et al., 2017).

2 Respondents learned about opportunities to engage in the third sector through such media as: posters $(26.9 \%)$, leaflets $(18.5 \%)$, social networks $(13.9 \%)$, radio/television $(10.2 \%)$, newspapers or magazines (6,5\%), billboards (3.7\%), banners (3,7\%), information brochures (2,8\%), e-mail (1, 9\%). 
The preparation of employees to function in third-sector entities should not however end with activities related to socio-occupational adaptation. Correct performance of tasks requires continuous improvement of employees' skills, e.g. through participation in training. It is important for them to develop specialized skills related to the organization's business profile, but also those that will be useful for solving typical third-sector issues (fundraising, image-building, establishing interpersonal relations with interested parties - subordinates, colleagues, founders). The results of the research point to the fact that only one in three respondents (33.3\%) was provided with the opportunity to undergo training, the fourth part $(25.9 \%)$ to expand knowledge in the area of the organization's activity. Then, one in five (20.4\%) learned how to manage their time, and one-seventh - promote non-profit activities, build a positive company image $(15.7 \%)$ and raise funds $(13 \%)$.

The functioning of an organization requires the recognition of the needs of the individual workers and of the personalized approach to their satisfaction (cf. Willems 2013). Such analysis allows for the selection of appropriate forms of motivation. Due to the limited resources of the third sector, the financial opportunities of employees are hindered. Deficits in this area can be offset by the use of intangible forms of motivation, e.g. by providing members of the organization with training (cf. Costa et al., 2006), offering flexible working hours, increasing their responsibilities, including placing them on managerial positions. Third-sector organizations are able to motivate by creating conditions for personal growth. More than half of the participants $(51.9 \%)$ were entrusted with responsible tasks. More rarely (43.5\%) were they improved by assigning responsibilities that required independence. One in four $(26.9 \%)$ grew personally by performing highly diverse tasks, thus eliminating monotony. A similar number of young workers $(24.1 \%)$ participated in company projects. Every eighth $(13.9 \%)$ took part in cyclic meetings that exchanged experiences and opinions with other members of the non-profit organization. These actions strengthened the commitment of the respondents in their social work by meeting the need of skill development (cf. Cnaan et al. 2010; Cordeaux 2017).

Research results indicate that non-governmental organizations have also created for some of the respondents conditions to meet the need for affiliation. Almost half $(47.2 \%)$ experienced a pleasant atmosphere at work, more than one in three (37\%) were interested in their activities, and one in five $(22.2 \%)$ participated in integration events. It should be additionally noted that nonprofit organizations have taken care of the need to recognize the respondents by: giving praise and thanks (in writing, 51.9\%, in speech - $25 \%$, in newsletters

Young people as a subject of human resources management in the third sector 
or online $-13 \%$ ), informing about the impact of the volunteer for the operation of the non-profit entity (14.8\%), placing his or her name in the annual report or in the publication that he or she helped prepare $(6.5 \%)$. The ideas of the people surveyed in terms of the activities of the organizations they were participants of $(11,11 \%)$ were taken into account as well. There were also tangible incentives, such as prizes and gift items (18.5\%), organization logo gadgets $(15.7 \%)$, free tickets to the gym, cinema, theater $(10.2 \%)$, financial rewards $(5 \%)$. Nearly every third respondent (28.7\%) believed they were not being motivated to work.

An important personal process in each organization is the evaluation of employees, as it fulfills, among others, informative and motivating functions. The research analyzed the universality of the use of professional evaluations in thirdsector entities. It was found that only $8.3 \%$ of the respondents received feedback on their results using the evaluation forms, whereas one in three $(28.7 \%)$ were notified of such during informal discussions. The majority (63\%) was not evaluated at all. This can be explained by the reluctance of members of the discussed organizations to excessive formality, which affects internal relationships. Third-sector players often involve a small number of staff whose relationships tend to be direct, generally friendly. A formal evaluation of such structures could have a negative impact on these relationships. In addition, the evaluation process in the discussed entities is often hampered by the democratic manner of management and the similarity of positions held within the staff team.

To sum up, the management of staff in third-sector organizations is not well known in formal procedures (professional tools and techniques specific to the business sector). More often it relies on the use of a network of interpersonal relationships and personal commitment. Young people engage in non-profit activities as a result of the unintentional interactions of significant people in the immediate community. The most important role of the personal processes such as socio-occupational adaptation, growth, motivation, and evaluation, are the actions of managers, based on the formation and development of partnerships and close ties with social workers. This, in turn, reveals the tendency of managers to limit the methods that bureaucratize management in the sphere of social organization of the third sector. Furthermore, it implies the occurrence of a specific, less formal atmosphere in the investigated entities.

\section{Conclusions}

Every citizen can join in the management of a specific area of the social sphere (e.g. social assistance, local development, education, etc.) in modern 
society by working with non-profit organizations. A significant segment of the employees of the third sector is young people whose involvement in the activity of these actors is an expression not only of civic attitude, but also of the opportunity to meet various needs, including the development of skills sought after in the labor market and the acquisition of professional experience. This requires third-sector managers to wisely use and adapt HRM methods and tools.

The research confirms that young people's participation in social management is seldom persistent and formal. Nearly half of the respondents were involved in the activity of only one non-profit organization (mostly social and humanitarian, rescue). Their activity was most often confined to one-off actions, voluntarily assumed tasks. Their accession to the organization was reported mainly as stemming from informal influence from educators, family members and friends. Most received support in the process of socio-occupational adaptation.

Every third respondent stated he or she was not motivated to work in the organization they were active at. Others have been able to meet some of their needs, among them: affiliation (e.g. by being able to work in a relaxed atmosphere, feeling others are interested in their activity, participating in integration events), recognition (e.g. by receiving compliments and thanks, gaining influence over the functioning of the organization developing own ideas for the activities of a third-sector entity), growth (e.g. during training, primarily in the non-profit area, improving interpersonal skills, self-organization, learning to build and promote a positive image of third-sector actors and raising funds). On the other hand, over half of the respondents did not have their work evaluated and only one in three received feedback on the results of their work.

The majority of the respondents positively evaluated their experiences in cooperation with non-governmental organizations. This could be influenced by strong internal motivation, but also, to a certain extent, the actions taken by the management staff to satisfy some of their needs. The research has demonstrated that it is important to establish and develop close, informal, personal and partner relationships in the process of managing social workers.

\section{Summary}

Young people as a subject of human resources management in the third sector organizations

In democratic societies, citizens join as volunteers in the management of various areas of the social sphere. They do this by engaging in non-profit organizations' activities. People are the 
basis for the functioning of these entities, so it is possible to use appropriately adapted HRM methods and tools.

The important part of the social workforce of non-profit organizations is young people (up to the age -of 26). The article presents the results of research on the experiences of young volunteers - the characteristics of their involvement and their participation in personnel processes.

The purpose of the article is to identify the number and types of third-sector organizations, which young people have been involved in, as well as the characteristics of work performed by them in those subjects.

Moreover, the article's aim is to diagnose of personal processes that these persons have been engaged in and to ascertain how do they evaluate their work experience in the organizations, which were analyzed.

Keywords: third sector, young people, commitment, human resources management.

\section{Streszczenie}

Młodzi ludzie jako podmiot zarządzania zasobami ludzkimi w organizacjach trzeciego sektora

W demokratycznych społeczeństwach, obywatele włączają się jako wolontariusze w zarządzanie różnymi obszarami sfery społecznej. Czynią to, angażując się w działalność organizacji non profit. Podstawą funkcjonowania tych podmiotów są ludzie, dlatego możliwe jest zastosowanie, odpowiednio zaadaptowanych, metod i narzędzi HRM.

Istotną część personelu społecznego organizacji non profit stanowią ludzie młodzi (do 26. roku życia). W artykule przedstawiono wyniki badań dotyczące doświadczeń młodych wolontariuszy charakterystyki ich zaangażowania oraz udziału w procesach personalnych.

Celem artykułu jest ustalenie liczby i typów organizacji trzeciego sektora, w które byli zaangażowani młodzi ludzie oraz charakteru wykonywanej w nich pracy. Ponadto, zdiagnozowanie procesów personalnych, w których uczestniczyli oraz stwierdzenie, jak oceniają swoje doświadczenia związane z zaangażowaniem $\mathrm{w}$ analizowane organizacje. 


\section{Słowa}

kluczowe: trzeci sektor, młodzi ludzie, zaangażowanie, zarządzanie zasobami ludzkimi.

JEL

Classification: A14, J81, M12, L31

\section{References}

1. Adamiak P., Charycka B., Gumkowska M. (2016), Kondycja sektora organizacji pozarzadowych $w$ Polsce 2015. Raport $z$ badania, Stowarzyszenie Klon/Jawor, Warszawa.

2. Ahmed R. (2013), Employee Recruitment and Selection Procedures of NGOs in Bangladesh: A Study on BRAC, "Asian Business Review" Vol. 2, No. 1, Iss. 3, pp. 24-30.

3. Anheier H. (2005), Nonprofit Organizations: Theory, Management, Policy, Routledge, New York.

4. Baluch McCandless A. (2012), Human Resource Management in Nonprofit Organizations, Routledge, New York.

5. Bartoszek A., Dąbrowska-Pięda I. (2009), Zarządzanie zasobami ludzkimi w organizacjach pozarzadowych, [in:] Barański M. (ed.), Zarzadzanie organizacja pozarzadowa w Unii Europejskiej, Wyd. Śląsk, Katowice.

6. Baranyi E.E. (2011), Volunteerism and Charitable Giving among the Millennial Generation: How to Attract and Retain Millennials, Dissertations, Theses and Capstone Projects, Paper 451, Kennesaw State University, Kennesaw.

7. Bogacz E. (2009), Zarzadzanie kadrami w organizacjach pozarzadowych, [in:] Bogacz-Wojtanowska E., Rymsza M. (eds), Nie tylko spotecznie. Zatrudnienie $i$ wolontariat $w$ organizacjach pozarzadowych, ISP, Warszawa.

8. Burke R.J., Cooper C.L. (2012), Human Resource Management in the Non profit Sector: Passion, Purpose and Professionalism, Edward Elgar Publishing, Cheltenham.

9. Bussell H., Forbes D. (2002), Understanding the volunteer market: The what, where, who and why of volunteering, "International Journal of Nonprofit and Voluntary Sector Marketing", No. 7, pp. 244-257.

10. Ciekanowski Z. (2010), Metody wdrażania i proces adaptacyjny pracowników, Powiatowy Urząd Pracy w Płońsku, Płońsk.

11. Cnaan, R. A., Smith, K. A., Holmes, K., Haski-Leventhal, D., Handy, F., Brudney, J. L. (2010), Motivations and Benefits of Student Volunteering: Comparing Regular, Occasional, and Non-Volunteers in Five Countries, "Canadian Journal of Non profit and Social Economy Research" Vol. 1, No. 1, pp. 65-81..

12. Cordeaux R. (2017), Young People E Nonprofit Work, Imagine Canada, Toronto. 
13. Costa C.A., Chalip L., Green B.Ch., Simes C. (2006), Reconsidering the Role of Training in Event Volunteers' Satisfaction, "Sport Management Review" Vol. 9, Iss. 2, pp. 165-182, https:// doi.org/10.1016/S1441-3523(06)70024-9.

14. Day N. (2013), Managing Volunteers: how to maximize your most valuable resource, Praeger, Santa Barbara.

15. Drucker P. (1995), Zarzadzanie organizacja pozarządowa. Teoria i praktyka, Fundusz Współpracy, Warszawa.

16. Fudaliński J. (2013), Perspektywa rozwoju zarządzania społecznego w sektorze organizacji non profit w Polsce, Difin, Warszawa.

17. Gliński P. (2006), Style działań organizacji pozarządowych w Polsce. Grupy interesu czy pożytku publicznego, IFiS PAN, Warszawa.

18. Hudson M. (1997), Bez zysków i strat. Sztuka kierowania organizacjami sektora pozarzadowego, Fundusz Współpracy, Warszawa.

19. Kafel T. (2014), Metody profesjonalizacji organizacji pozarządowych, Wydawnictwo UE w Krakowie, Kraków.

20. McGinnis J. (2011), The young and restless: generation $Y$ in the non profit workforce, "Public Administration Quarterly" Vol. 35, No. 3, pp. 342-362, DOI: $10.2307 / 41506761$.

21. Mulhare E.M. (1999), Mindful of the future: strategic planning ideology and the culture of nonprofit management "Human Organization” Vol. 58, No. 3, DOI: 10.17730/humo.58.3.975v78735176943v.

22. Penc J. (2007), Nowoczesne kierowanie ludźmi. Wywieranie wptywu i wspótdziałania w organizacji, Difin, Warszawa.

23. Pynes J. E. (2013), Human Resources Management for Public and Nonprofit Organizations, Jossey Bass, san Francisco.

24. Rodwell J.J., Teo S.T.T. (2008), The influence of strategic HRM and sector on perceived performance in health service organizations, "The International Journal of Human Resource Management", No. 10, pp. 1825-1841.

25. Rustecki W. (ed.) (2011), Praktyczny poradnik wspótpracy z wolontariuszami, Fundacja Pracownia Badań i Innowacji Społecznych Stocznia, Warszawa.

26. Stankiewicz J., Bortnowska H., Seiler B. (2017), Zaangażowanie młodych uczestników rynku pracy w dziatalność organizacji pozarządowych jako czynnik sprzyjający rozwojowi kompetencji zawodowych (w świetle wyników badań), "General and Professional Education", in press.

27. Vijaya B., Karibasaveshwara B. (2014), Recruitment and selection practices in NGOs: a study with reference to selected NGO's in Gulbarga district, "International Journal of Economic and business Review" Vol. 2 Iss. 11, pp. 201-207.

28. von Eckardstein D., Brandl J. (2004), Human Resource Management in Nonprofit Organizations, [in:] Zimmer A., Priller E. (eds), Future of Civil Society, VS Verlag für Sozialwissenschaften, Wiesbaden, 297-314. 
29. Weber M. (2011), Racjonalność, władza, odczarowanie, Wydawnictwo Poznańskie, Poznań.

30. Wciseł W. (ed.) (2015), Podręcznik zarządzania NGO, Europejski Dom Spotkań - Fundacja Nowy Staw, Warszawa.

31. Willems J. (2013), The Volunteer Satisfaction Model: A Practical Framework to Improve Volunteer Management Practices, available from the author through www.ResearchGate.net, (24.08.2017 - access date).

32. Wolontariat w organizacjach - 2016. Wstępne wyniki badania "Praca niezarobkowa poza gospodarstwem domowym" (2016), Główny Urząd Statystyczny, Warszawa.

33. Żarczyńska-Dobiesz A. (2008), Adaptacja nowego pracownika do pracy w przedsiębiorstwie, Wolters Kluwer, Kraków. 